ORNL -4472

UC-7C - Waste Disposol and Rrocessing

LOW-LEVEL RAOIOACTIVE WASTE TREATMENT:

THE WATER RECICLE FRDCESS

W. C. Yee

F. Deloro

W. E. Shockley

THIS DOCUMENT CONFIRMED AS UNCLASSUHEO

DIVISIONOF CLASSIFCATION

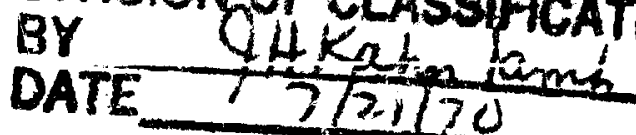

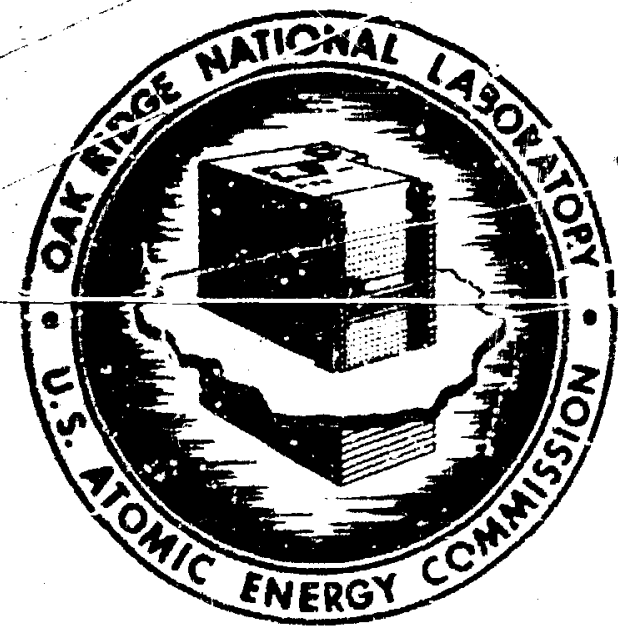

OAK RIDGL NATIONAL LAEORARORY

$$
\text { operate: by }
$$

UNION CALBIDE CORPORATICIN

fer ine

U.5. ATOMIC EAERG COMMISSION 


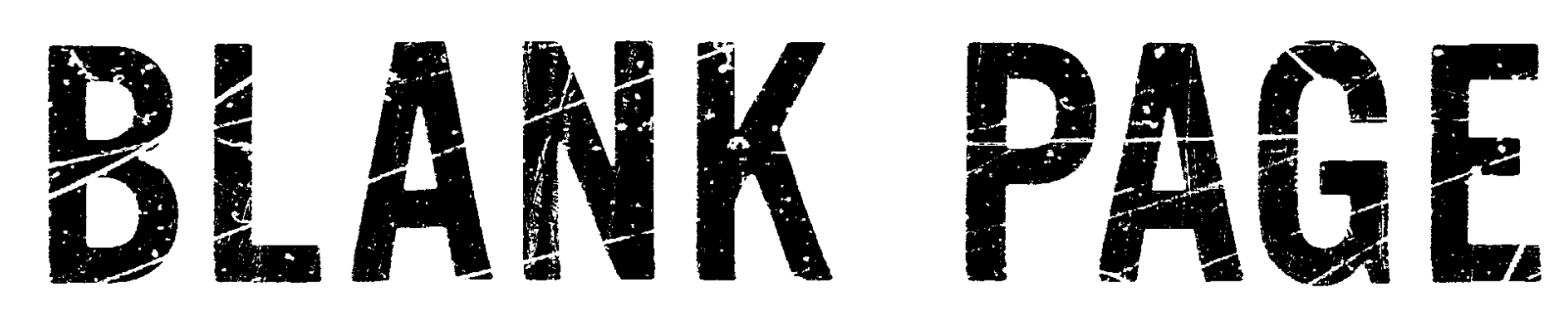




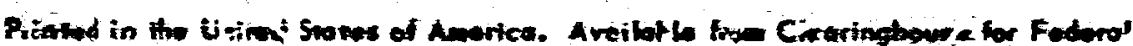

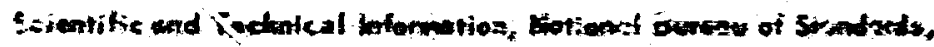

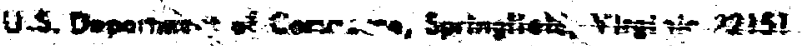

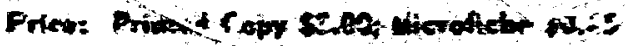

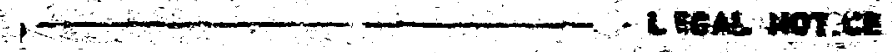

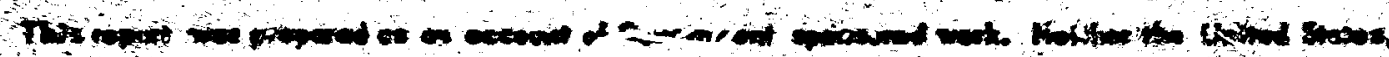

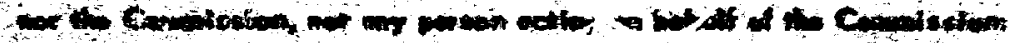

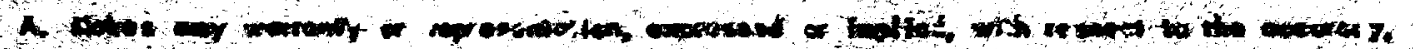

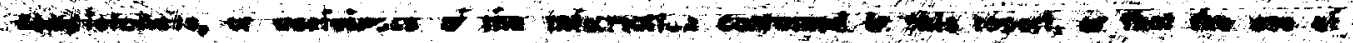

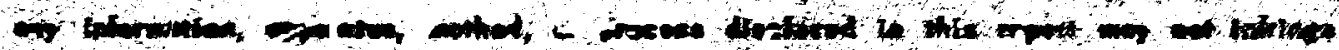

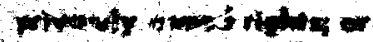

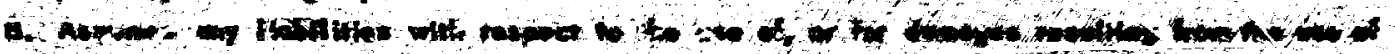

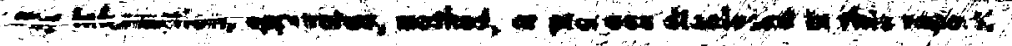

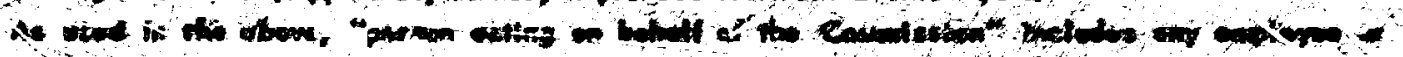

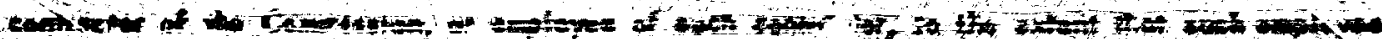

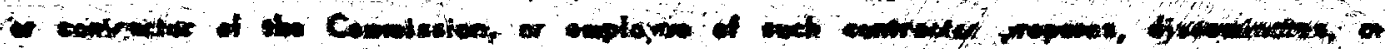

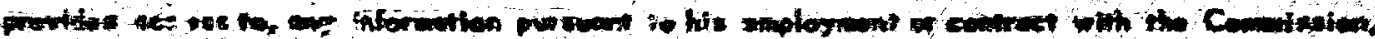

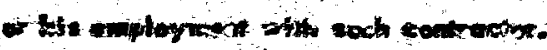




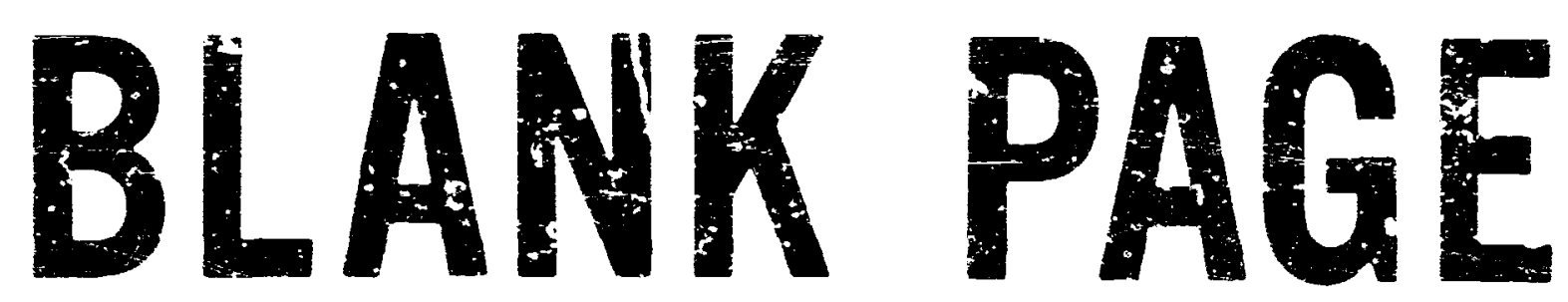


Coniract No. $W-7405$-eng-26

CHEMICAL TECHNOLOGY DIVISION

Chemizai Development Section $B$

LOW-LEVEL RADIOACTIVE W'ASTE TREATMENT: THE WATEP RECYCIF PROCESS

W. C. Y'ee

F. Delora*

W. E. Shockley

Ihis repor: was prepared as an account of work sponsored by the United States Government. Veither the Uniter St tes nor th= United States Atomic Energy

Commission, nor any of their emplostes, not any of their contractors. subcontracturs, or their emplovees, makss any warranty, express or impit 1, or assumles any lepal liability or responsibi'ity for the accuracy, completeness or usefuiness of 3 no information, apcaratus,

product or process disclosed, or represents that its use would not infringe privacely owned rigrits.

JULY 1970

* Guest scientist from the Spanish Atomi= Energy Commission. Present Address: Ministerio de Industria, Junta de Erergia Nuclear, Madrid, Spain.

OAK RIDGE NATIONAL LARORATORY

Oak: Ridge, Tennessee

operated by

UNION CARBIDE CORPORA TION

for the

U. S. A TOMIC ENERGY COMMISSICN 
W. C. Yee, F. DeLors, * and W. E. Shockley

\section{A BS TRACT}

The $w$ ster recycle process was developed for decontaminating low-ievel radioactive aqueous wastes and recycling the purified water

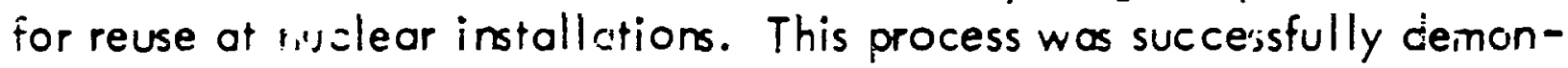
strated through severa! cycies in a micro-pilot plant; using CRNL waste that contained low concentrations of selts and icdicruclides. The recycle of water should be ar. improvement over present methods in which the wastej are tecontaminated and the purified water is discharged to the envirunment. The steps in: the process are: (1) clor= ification, using zeta-potential-controlled additions of coagulants such as alum, coagulant aids, activated silica, and nonionic organic polyelectrolyte; (2) demineralization by cation-anion exchange; and (3) treatment with activated carbon. Zeta-potential contral was shown to be an excellent method for obtcining cptimum clarification conditions. The water in the micio-rilot planit was decontaminated from all major radionuclides by factors (DF's) of 1000 to 10,000 for up to 2400 volumes of water per volur: 2 of cation resin. The DF's for cobait $\left({ }^{50} \mathrm{Co}\right)$ and ruthenium ( ${ }^{106} \mathrm{Ru}$ ) were $10^{4}$ and $10^{3}$, the highest obtained in the ORNL waste development program.

\section{INTRODUCTION}

Low-level radioactive wastes, consisting of viater with iow concentrations of scilts and radionuclide, are produced ot most nuclear installations. Comentiona! decontamination methods ${ }^{1,2}$ inc'ude sccivenging precipitation, ion exchange, or distillation, followed by discharge of the purified water to the environment. The obje..ives of the work reported here are: (1) to determine the technical feasibility of incycling tie purified water for reuse (e.g., to determine the effects of the

\footnotetext{
-Guest scientist from the Spanish Atomic Energy Commission. Present oridress:
} Ministerio de Industria, Junta de Energia Nuclear, Madrid, Spain. 
- uncentrations of cortaminants in rec; sled water; ain ' is; to develop improved decontamination methocs. Recycle appears desirable since it would eliminate the cost of purifying the water that is taken from rivers for use in the nuclear station: also, it woula allow the nuclear station to become self-contained. Improved decontamination would, of course, decrease she flow of radionuclides to the environment. The radioctive concentrate could be incorporated in asphalt oi polyethylerve pricr :o disposal in a government burial grourd. 3,4

Sorne of the solids in the waste are present in the form of colloidal particles. Thus, efficient clarification is important as the first treatment step. Zeta-notential control was developed as a regulatory method since previous workers had reported that it showed considerabie promise."

The second step is demineralization for efficient removal of soluble scits and radionuclides. This portion of the process differs from the previously developed process $^{6-9}$ in which a high degree of decontamination, but only partial demineralization, was achieved. The third step is sorption on activated carbon. This sorption system was evaluated in an effort to increase the removal of radionuclides, such as ruthenium and cobalt, wi ich had proved to be refractory in previous studies.

The water recycle process is compatible with present public opinion and with government policies that encourage the recirculation of waters and the minimization of discharge of both radioactive and norradioactive solts to the envirorment. 10 This type of prosess should also be applicable to the recycle of nonradioactive industrial and urban waste waters that require clarification cad demineiclizatizn.

\section{PROCESS FLOWSHEET}

The water recycle process, which was jeveloped for the treaiment of low-level radioactive waste having a low salt content (Fig. 1), consists of the following steps: coagulation and clarification, demineralization, and treatment with activated carbon. Tte decontaminated and demineralized water is returned to the nuclear 


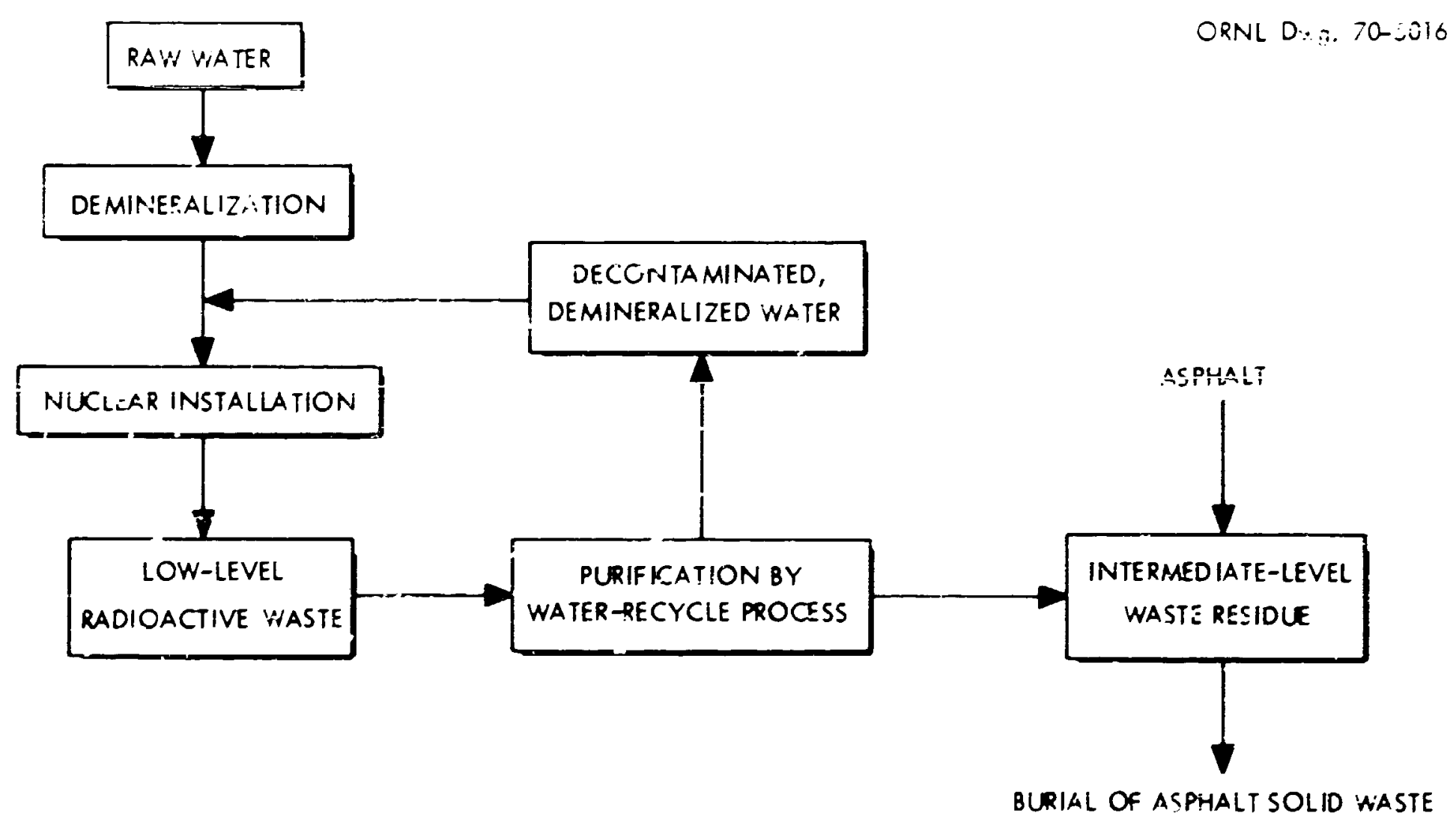

Fig. i. Treatment of Low-Level Rodioactive Waste and Disposal of Residues. 
installation for reuse, while the corcentrated radioactive waste is denitrated, if necessary, and then incorporated into asphalt and buried.

The flowsheet (Fig. 2) includes: (1) coogulation by zeto-potential-controlled additions of the coogulant, alum, and the coagulant aids; activated silica; and o nonionic organis polyelectrolyte; (2) clarification by upflow through a fluidized bed of sludge (upflow clarifier), followed by filtration through a bed of anthracite ccal and sand; (3) deninerclization by cation-anion exchange; and (4) sorption of the emairing radiosciive and norradisactive contaminants on granular activated camon. Continuous operation of the cosgulation-clarification systen: under optimum conditians is importont to the moinitenance of high decontamingtion factors (DF's) for radionuclides such as cobalt and ruthenium, which, in neutral wastes, exist in several forms ixcluding ioric and nonionic colloids. Efficient removal of these collcids depends on the neutralization of their mutually repelling surface charges, that is, their zeta-potential (ZP). ${ }^{5}$ The successive addition of activated silica $(0.5 \mathrm{kmm}$ as $\mathrm{SiO}_{2}$ ) and alum $\left[2\right.$ to 3 ppm as $\left.\mathrm{Al}_{2}\left(\mathrm{SO}_{4}\right)_{3}\right]$ in the flash mixer increased the $Z \mathrm{P}$ of synthetic recycle water from $-20 \mathrm{mv}$ to $+3 \mathrm{mv}$. Stirring at $1750 \mathrm{rpm}$ effectively enmeshed the colloids within the freshly formed aluminum hydroxide floc. The addition of $75 \mathrm{ppb}$ of a nonionic orgunic polyelectrolyte* at the flocculator enhanced the growth and settling properties of the floc (Fig. 3) and acccmplished the desiret filtering action in the upflow clarifier (ihe primary filtering medium) by misintaining a fiuidized bed of sludge. The fina! $Z \bar{F}$ was $-2 \mathrm{mv}$. After filtration through anthracite and sand, the water had a ciarty comparabie to that of cilsilited woter, represeriting a greater than 100-fold decrease in turbidity. The micro-pilot plant components used in these tests are shown in Figs. 4 and 5.

Demineralization was accomplished by ion exchonge, using two separate columns; one contained 1.0 cation resin :olume $(400 \mathrm{ml})$ of a strong -ucid cation resin (Dowex $50 \mathrm{~W}-\times 8,20$ rc 50 mesh), and the other contained 1.9 cation resin volumes $(750 \mathrm{ml})$

"Purifloc N-12, product of the Dow Chemical Co., Midland, Mich. 


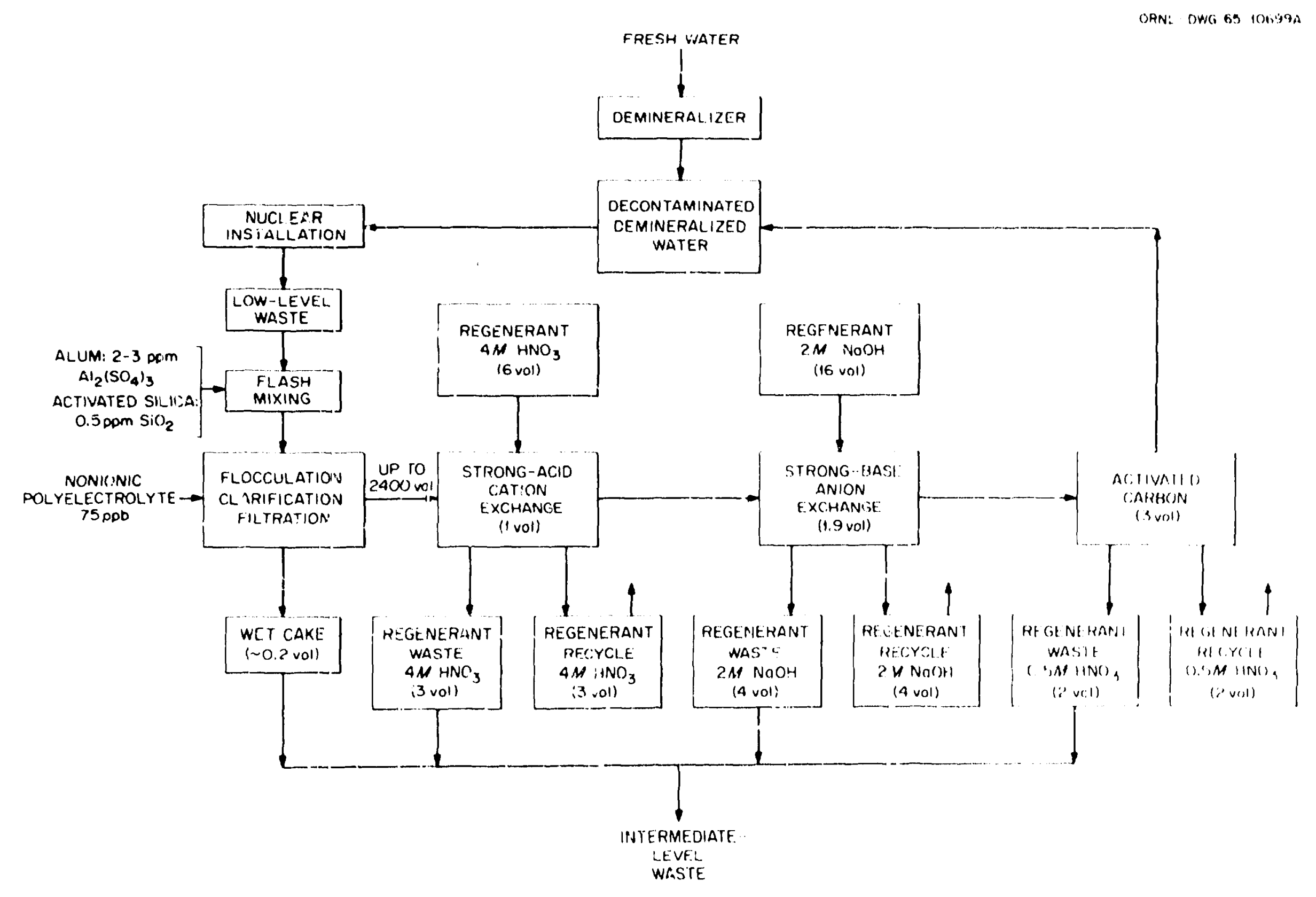

Fig. 2. Flowsheet for the Water Recycle Fiocess 

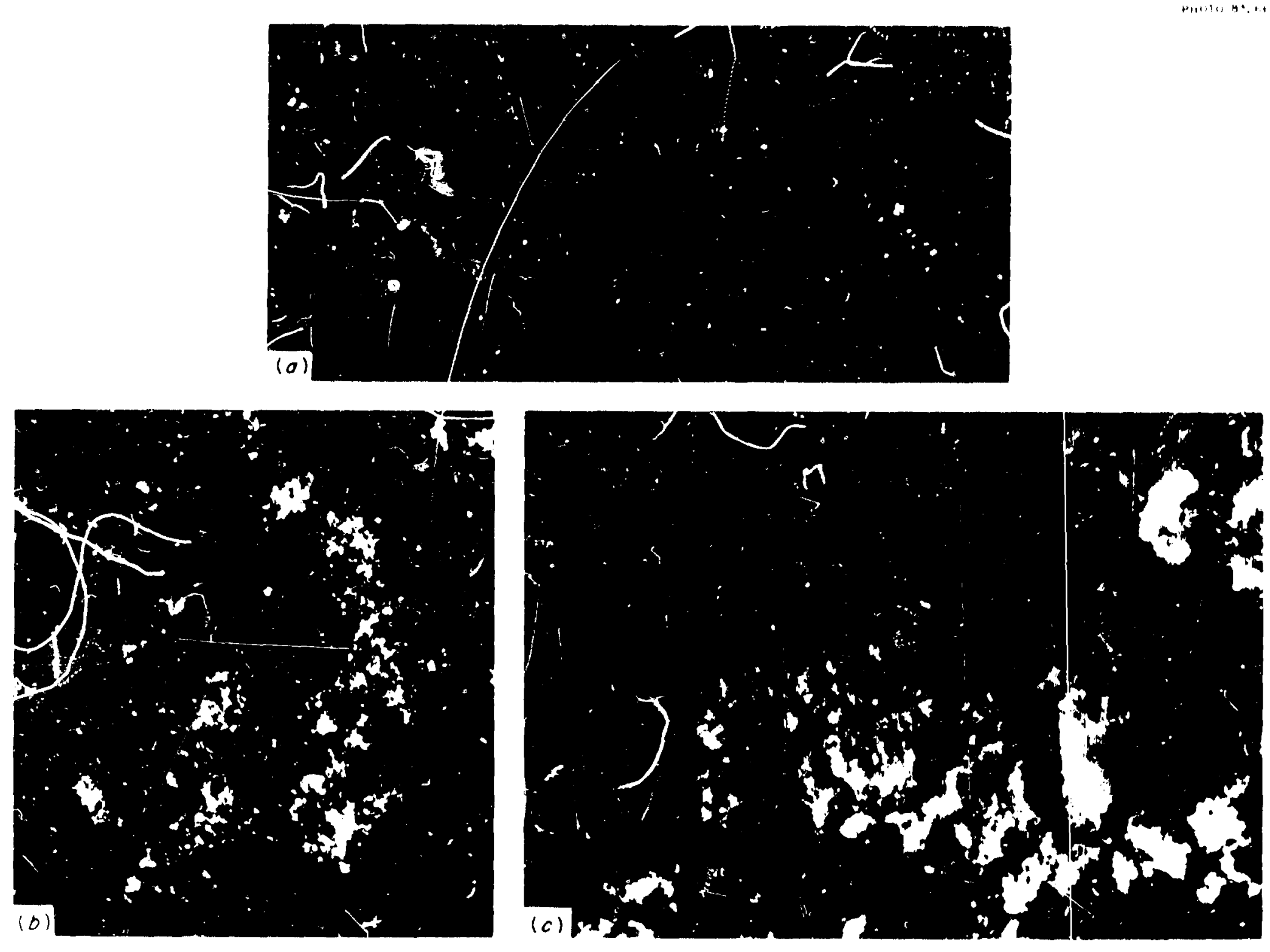

Fig. 3. Coagulation of Suspensoids by Use of Zeta-Puiential Control. (a) Raw weter contains suspena:d particles which have an average zeta potential (ZP) of $-20 \mathrm{mv}$. (b) Alum [2 to $\left.3 \mathrm{ppm} \mathrm{Al}_{2}\left(\mathrm{SO}_{4}\right)_{3}\right]$ and octivated silica $\left(0.5 \mathrm{ppm}\right.$, as $\left.\mathrm{SiO}_{2}\right)$ are added with rapid stirring. Repulsive surface charges are neutraliz.ed to a $\mathrm{ZP}$ of $+3 \mathrm{mv}$, and particles (the "stars") are enmeshed into the freshly formed smiall aggregates of alumirium hydroxide floc. (c) Floc growth is enhanced by the addition of a nonionic organic polyelectrolyte (75 ppb) which lowers the $Z P$ to $-2 \mathrm{mv}$. The water, after filtration, has a clarity comparable to that of distilied water. 


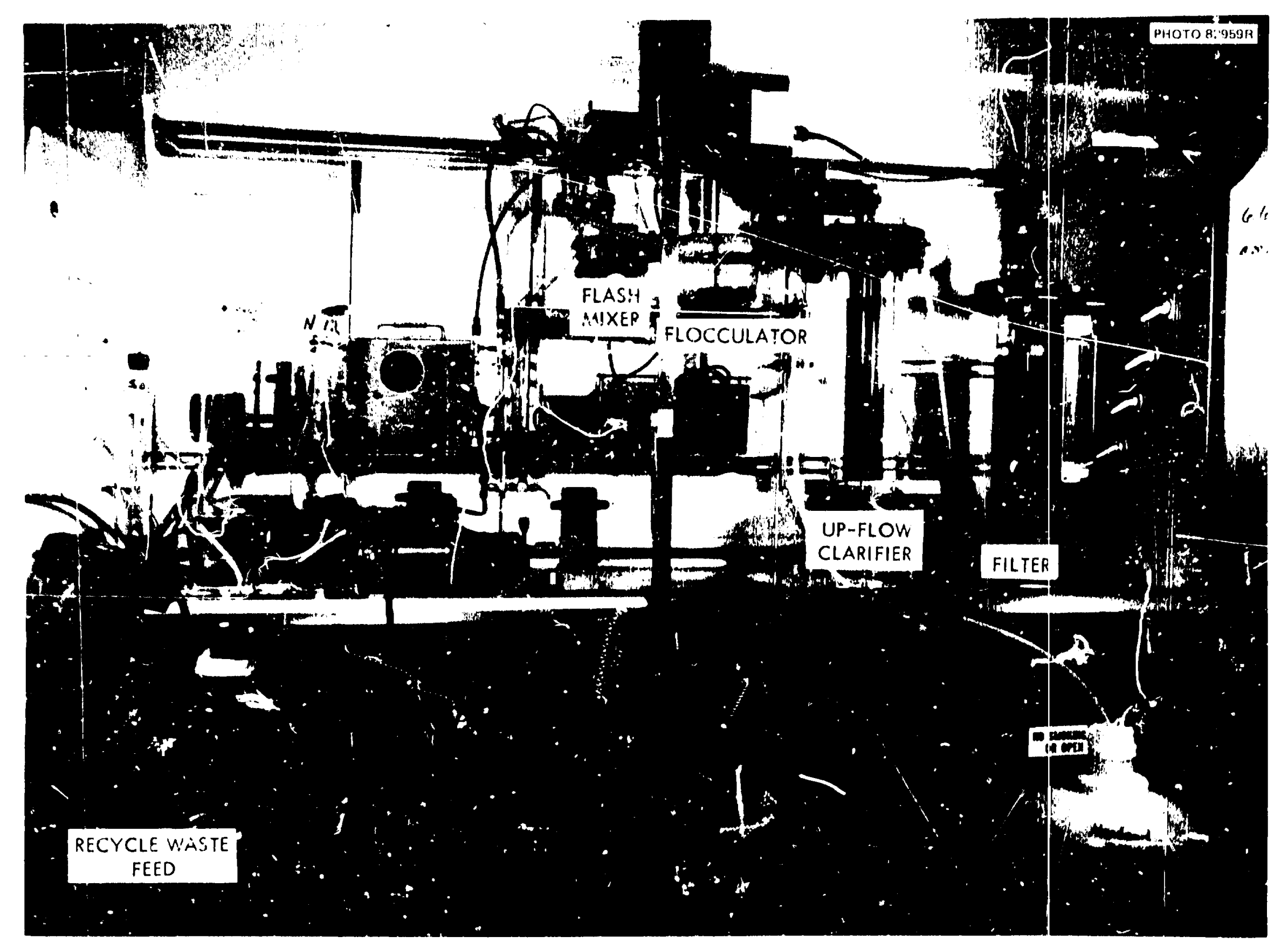

Fig. 4. Micro-Pilot Plant Used in Tests of the Water Recycle Process: Clarification Section. 


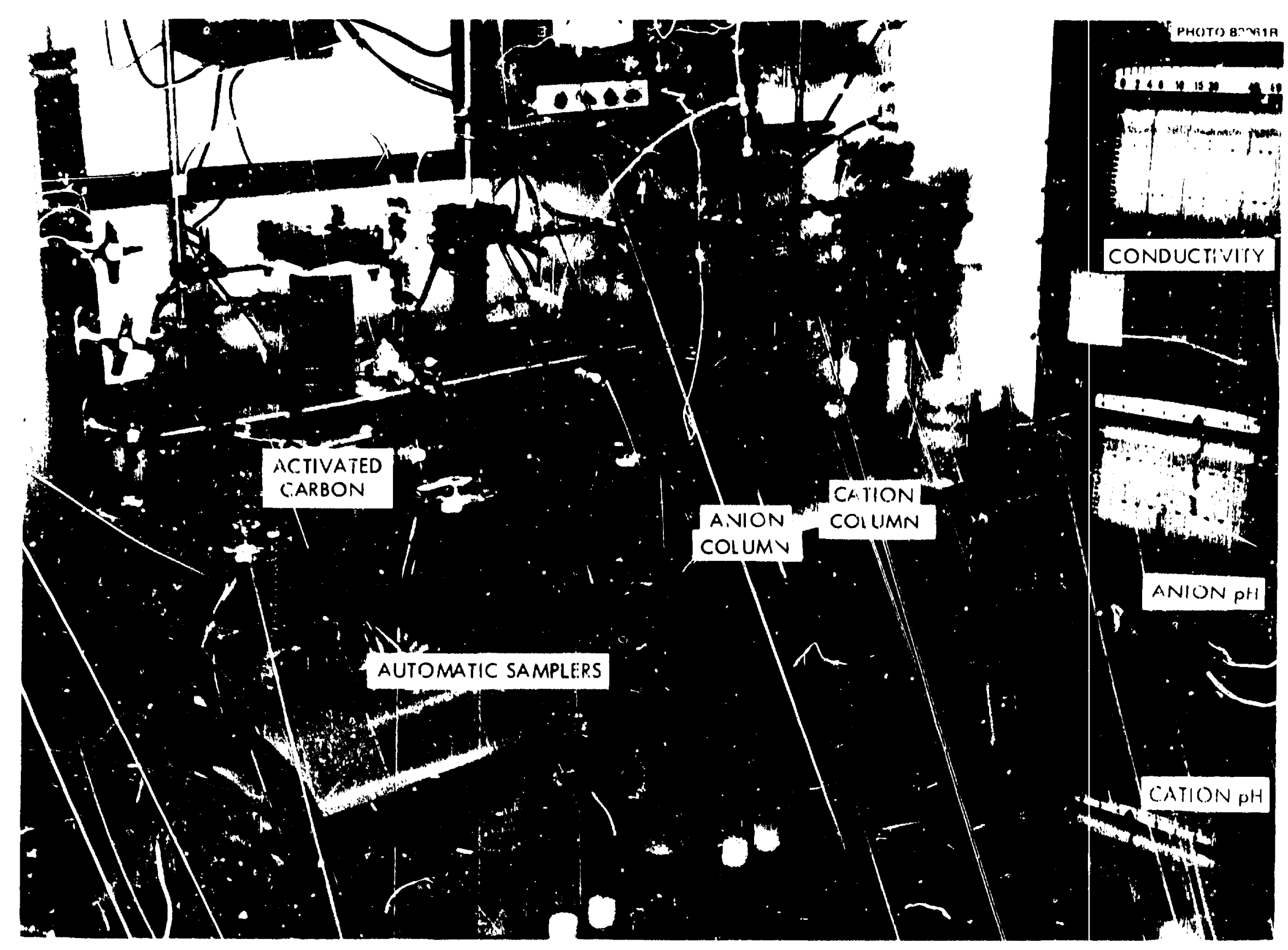

Fig. 5. Mirso-Filot Plant Used in Tests of the Water Recycle Process: Demineralization.. Carbon Sectioni. 
of a strong-base ani on resin (Dovex $i-x: 20$, 20 to mesh!. The contact times for the cation and anion columns wers 2.6 and $4.0 \mathrm{~min}$, respectively. The fium idie was $150 \mathrm{ml} / \mathrm{min}$. A third column, contcining activated carbon, was used for finai polishing (or cleaning). A vegetable-based gicnular, acti ated carben* was use $d$ in preference to other commercial carbons because of its grecier capacity for cobalt. The volume of the activated-carbon col:ren (i.e., $1200 \mathrm{ml}$ or 3.0 cation resin voluries) was maintained at three times that of the cution column to obtain the optimum residunce time of $8 \mathrm{~min}$ recommended by Robeits ard Abdel-Razek. 11

The water used in the micro pilot plant evaluation of the flowsheet had to be similar to water that had been demineralized and then recontaminared through plant use. Consequently, the waste used in these experimental rurs was water with a low solids content and consisted of: (1) $80 \%$, by volume, of decontaminated and demineralized ORNL-LLW trected via the water recycle procass, (2) 20\% row OKNL$L L W$, and (3) radicactive tracers. The specific conductance of the composite waste water was 80 to 100 microminos/cm, only one-fourtil to one-third of that for ORNLLLW. Equal amounts of tracer $106_{\text {R: }}$ were added from two sources, namely, an acid solution containing ${ }^{106} \mathrm{Ku}$ as the pure isotope, and ORNL intermediate-ievel waste $\left(\mathrm{pH}, 12\right.$ i 13) containing ${ }^{106}$ Ru Cobalt-úl from these two sources was also present. Overall DF's of 100 to $i C, 000$ for all major radiocctive species were obtained for up to 240 volumes of wasie treated per bed volume of cation resin; DF's in the few-thousand! range were achieved for ${ }^{131} 1,{ }^{106} \mathrm{Ru},{ }^{90} \mathrm{Sr}$, and total raie earths, while DF's of 14,000 and 37,000 wore achieves for ${ }^{i 37} C_{s}$ and ${ }^{60}$ Co respectively. The concentrations of other racionuclides - ${ }^{144} \mathrm{Ce},{ }^{125} \mathrm{Sb}$, and ${ }^{95} \mathrm{Zr}-\mathrm{Nb}$ - were reduced to the analytical limits of derection (Tobie 1). The DF's for ${ }^{106} \mathrm{Ru}$ and ${ }^{60} \mathrm{Co}_{\mathrm{O}}$ were $: 0$ to 1000 times higher thai those obtained previously in the ORNL waste cievelopment program. 12 the composition of the produrt waier met U. S. Public Health

\footnotetext{
*Nuchair C-190: a produst of West Virginia Pu!p and Paper Cr.., Chemical Division, New York, N. Y.
} 
Table 1. Product-Noter Añulysis of low-Salt-Connent Wuste Treated by the Water Ricyclo Procais"

A. Overall Decc ntamination Factors (DF's) for Rodionuclides

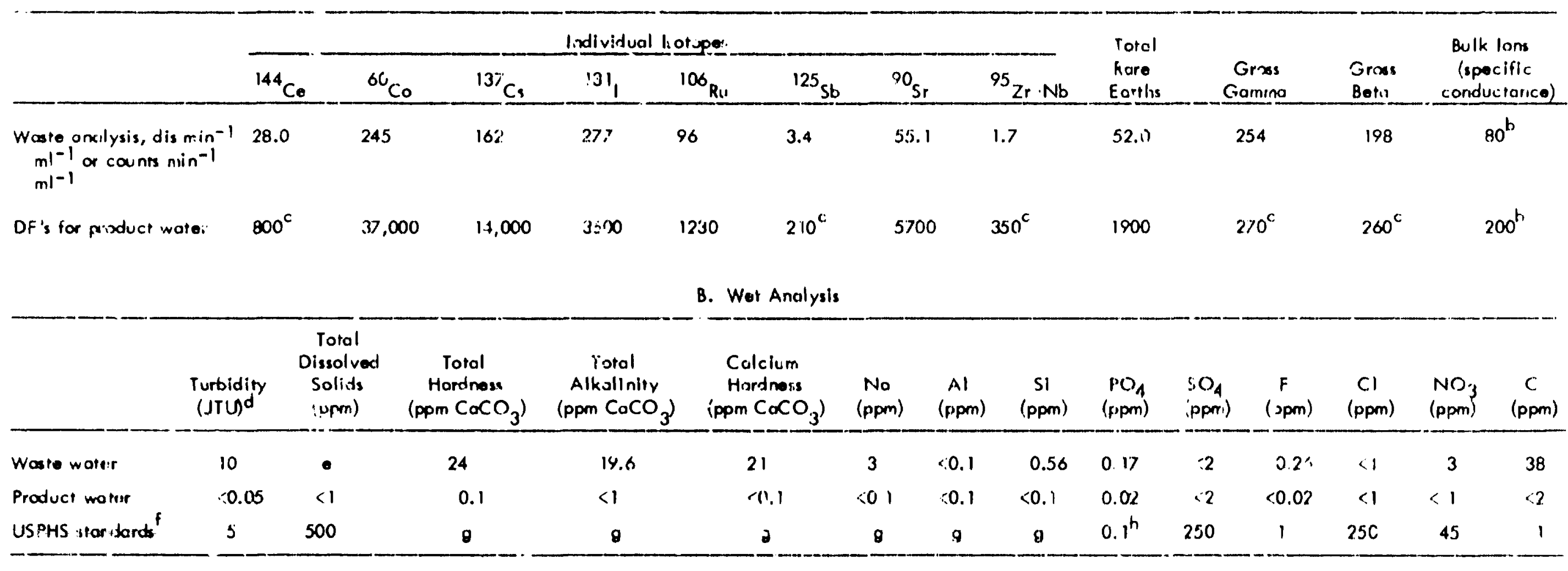

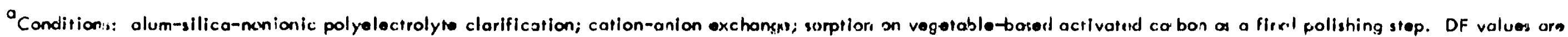
for produst water with is sperific consiuctance of low than 1 micromho/ $\mathrm{cm}$.

bThe dilinensions of specific coreluctance ore micromhos $/ \mathrm{cm}$.

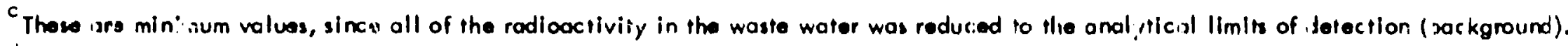

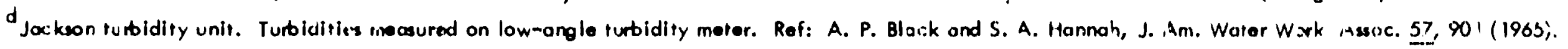

- Not durerinined.

'U. S. P. blle Hea!th Service Drinkina Water Standards, 1962.

No lin is given.

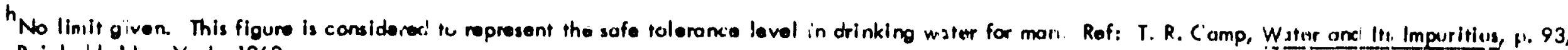
Rointeild, Itow York, 1963. 
Service specifications regarding permissible cuncentrations of radioactive elements 13 (i.e., < $2 \%$ of the MPC for a 158 -hr week if 131 is excluded; $<10 \%$ of the MPC if 131 is included) as well as nciradioactive elements. "it The solt content of the product waier was reduced to less than 2 ppm, i.e., greater than a 20 -fold redu:tion.

In the demineralization-carbon system, specific conductance was a simple ináicator of resin-bed exhoustion, since the breakthrough of bulk ions has been found to precede breokthroulh of the radioelements (Fig. 6). Ion exchonge trectrinent aione removed most of the ${ }^{137}$ is and ${ }^{90}$ Sr, but sorption on activated carbon was required in order is ostain high DF's for cobalt and ruthenium. The DF for demineralization, as indicured by specific conduciarce measurements (Table 1), was 200 .

The regereration of the cation exchange column required six resir volumes of 4 in $\mathrm{HNO}_{3}$ to reduce the activity level of the radioelements on the resin to $0.1 \%$ of the level of the sorption cycle; the first three bed volumes (BV's) containing the bulk of the activity were diverted to intermediate-level waste, whi! the lasi three BV's were retained for a subsequent regeneration. In similor fashion, 8 BV's of $2 \mathrm{M} \mathrm{NoOH}$ were required to reduce the concentrations of the rodicelements on the anian exchange colums to $1 \%$ of the origina!. Cobalt-60 was removed from the activated-carbon column $\mathrm{L}_{y}$ using $0.5 \mathrm{M} \mathrm{HNO}_{3}$ as the elvent; $4 \mathrm{BV}$ 's were required to reduce the octivity resuliing from this rodionuclide to $0.1 \%$ of that originaliy present.

Important parameters that could significantly affect the process operation in recycle water tn:atment include the $\mathrm{pH}$ of the raw waste, the specific condustonce of this waste, the synthetic-detergent content of the waste, and the effect of increased amounts of contaminants that may accumulate during recycle. The pH of the row waste must be in the range of 7 to 8 prior to coogulation-clarification treatment. This allows proper alum flor formation, which is essential to optimum rentoval of the radiocolisids, especially ${ }^{106} \mathrm{Ru}$ and ${ }^{60} \mathrm{Co}$. The required aium dose is more dependent oni the specific conductance of the waste than on the tutbidity of the woste; ORNLLLW with a specific conductance of 250 to 300 micromhos/cm and about 15 Jackson 


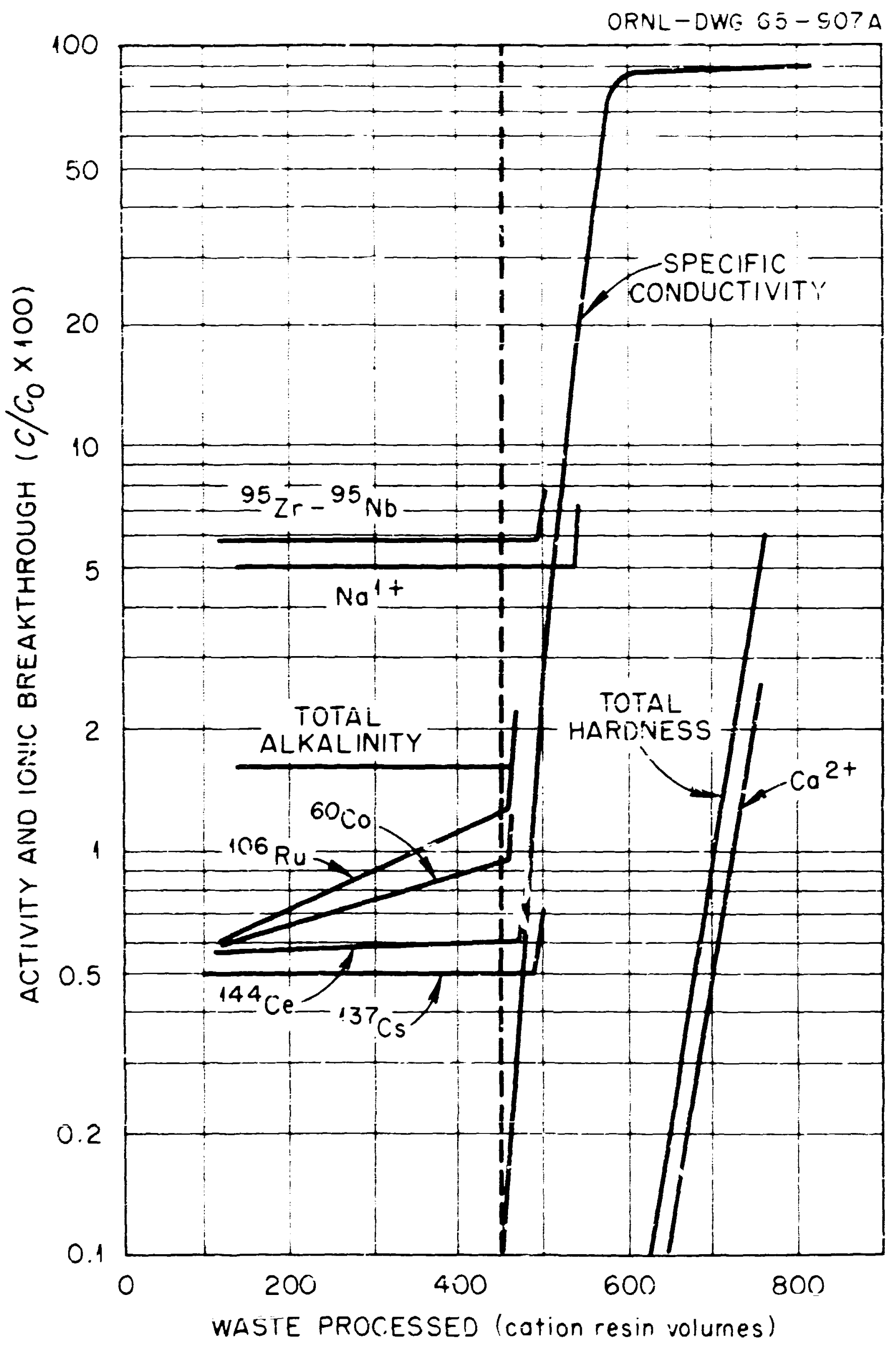

Fig. 6. Breakthrough of Bulk lons and Fadionuclides. Specific-conductance measurements signal imminent breakthrough of radionuclides because buik ions break through first. 
rutbidity uni's (JTU) :equired $20 \mathrm{ppm} \mathrm{Al} 2\left(\mathrm{SO}_{4}\right)_{3}$, while recycle waste with a specific conductance of 50 to 60 micromhos/cm and tutidities ranging from 5 to 25 JTU required cniy 2 ro 3 pDm Ai ${ }_{2}\left(S_{4}\right)_{3}$ (i.e., about one-tenth of the dose required for ORNL-LLW). Wher large concentrations of syntheric detergent (syndets) ore present in waste, the addition of a medium-long-chain cationic polyelectrolyte may be necessary ir, order to optimize clarification. This polyelectrolyte serves to decrease the negative ZP of the sispended porticles sufficiently to se:mit alum and activated silica to reutralize the surface charges. In one micro-pilot plant run, 10-ppm quantities of tripolyphosphate (TP) and alkylbenzenesulfonate $(A B S)$ were added to the recycle waste; the combined concentration of these compounds is comporable to the maximum syndet conceniration in secondanj effluent water, as reported by the U.S. rublic Health Service. ${ }^{15}$ In the coogulation step, opproximately $20 \mathrm{ppm}$ of Primafloc C-3,* approximately $15 \mathrm{ppm} \mathrm{of} \mathrm{Al}_{2}\left(\mathrm{SO}_{4}\right)_{3}$ and 0.2 ppm of activated silicu (as $\mathrm{SiC}_{2}$ ) were added. The addition of larger quantities of coagulants and coagulant aids significantly increcsed the totol dissolved solids present in the waste and msulted in the reduction of the ion exchange capacity for treating the waste by $33 \%$ (i.'s., to about 1500 BV's).

\section{LABORATCRY DEVELOPMENT OF I HE PROCESS}

Much of the laboratory work connested with the development of the water recycle process wos devoted to a careful examination of the conditions necessary to achieve optimum clarification of raw wastes on a continuous bosis, since the removal of the ionic radioactive contaminants could be readily accomplished via cationcnion exchcinge methods.

One of the most significant and controlling factors in the clorification of yste ircters is $2 \mathrm{~F}$ joniroi. ${ }^{16}$ Aithough several other foctors must also be taken

A medium-long-chain polyamine of the cationic type, with a molecu! ar weight of 10,000 to 20,000; product of Rohm and Haos Co., Philadelphio, Fo. 
into account, it is essentiol to neutralize the mutual repelling forces ( $Z P$ ) of the colloids since they keep the particles in suspersion and hinder or prevent agglomerotion. Coogulation is achieved when o suf:icient quan. iry of alum and other coogulants aids is added to encopsulate all the colloidal particles in hydrated aluminum oxide. Zero $Z P$ (with a tolerance of $\pm 5 \mathrm{mv}$ ) is atfained when the omptoteric oluminum oxide floc is at $6 \mathrm{pH}$ neor the isoelectric point.

Exploratory jor (or beaker) tests were made with ORNL-LLW to identify the optimum conditions needed to clarify waste water, using ZP control. Each test consisted of the following steps: (1) 2 min of flosh mixing (1750 rpm) of the woste water ofter alum was added; (2) $15 \mathrm{~min}$ of flocculation at $60 \mathrm{mpm}$, followed by 15 min of mixing of $20 \mathrm{rpm}$; and (3) $30 \mathrm{~min}$ of settling rims. Electrophoretic mobility measurements were mode, immediately ofter the flosh-mixing step, with the use of a Zeta-Meter; * these measurements were subsequently converted to $Z P$ values.

The avsroge ZP (using the above method) of somples of ORNL-LLW taken over a six-month period varied from -12 to $-18 \mathrm{mv}$ (Fig. $\lambda$; this range is slightly less negative than that for suspensoids in row water (reported 17 to be -16 to -22 rev). Test abjectives included the cietermination of: (1) the amount of alum reeded to bring the IP of the waste to zero, (2) the influence of other cooguloni oids sn zeto potential when they were added along with aium, and (3) the effect of speesi co: flosh mixing. Figure 8 shows thot 10 to $X \mathrm{ppm}$ of alum is needed to neutralize the negative $Z P$ for colloids (in woste) that hove initiol $Z P$ valuss ronging from -11 to $-18 \mathrm{mv}$.

The effects of coogulant oids on ZP (Tatle 2) are as follows:

1. Grundite cloy, which can be odded to give bulk to the ligint alum floc and tc decreose subsequent settling time for elerifiestient, rends to decrease the amoum of olum subsequently needed to uttain zoro ZP. (The ZP of Grundite clay in tap water is about $-10.8 \mathrm{mv}$, which is less negative than the overgge $Z P$ of the suspersoids in ORNL-LLW.)

*Product of Zeta-Meter, Inc, New York, N. Y. 
ORNL DWG 85-1847

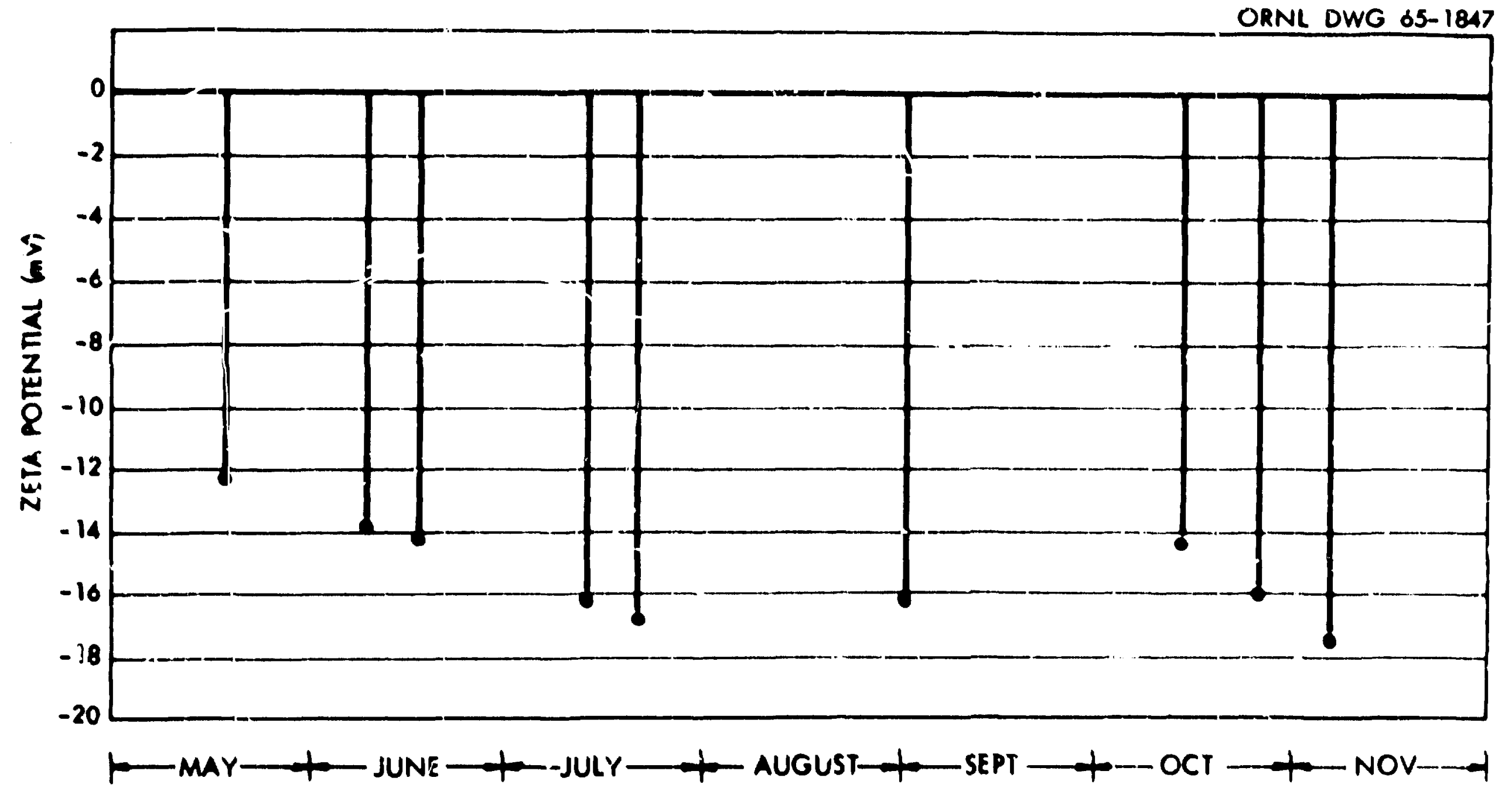

Fig. 7. Zera.-Potential Values for Samples of Row, Low-Levol Rodioactive Waste Taken in 1964. 


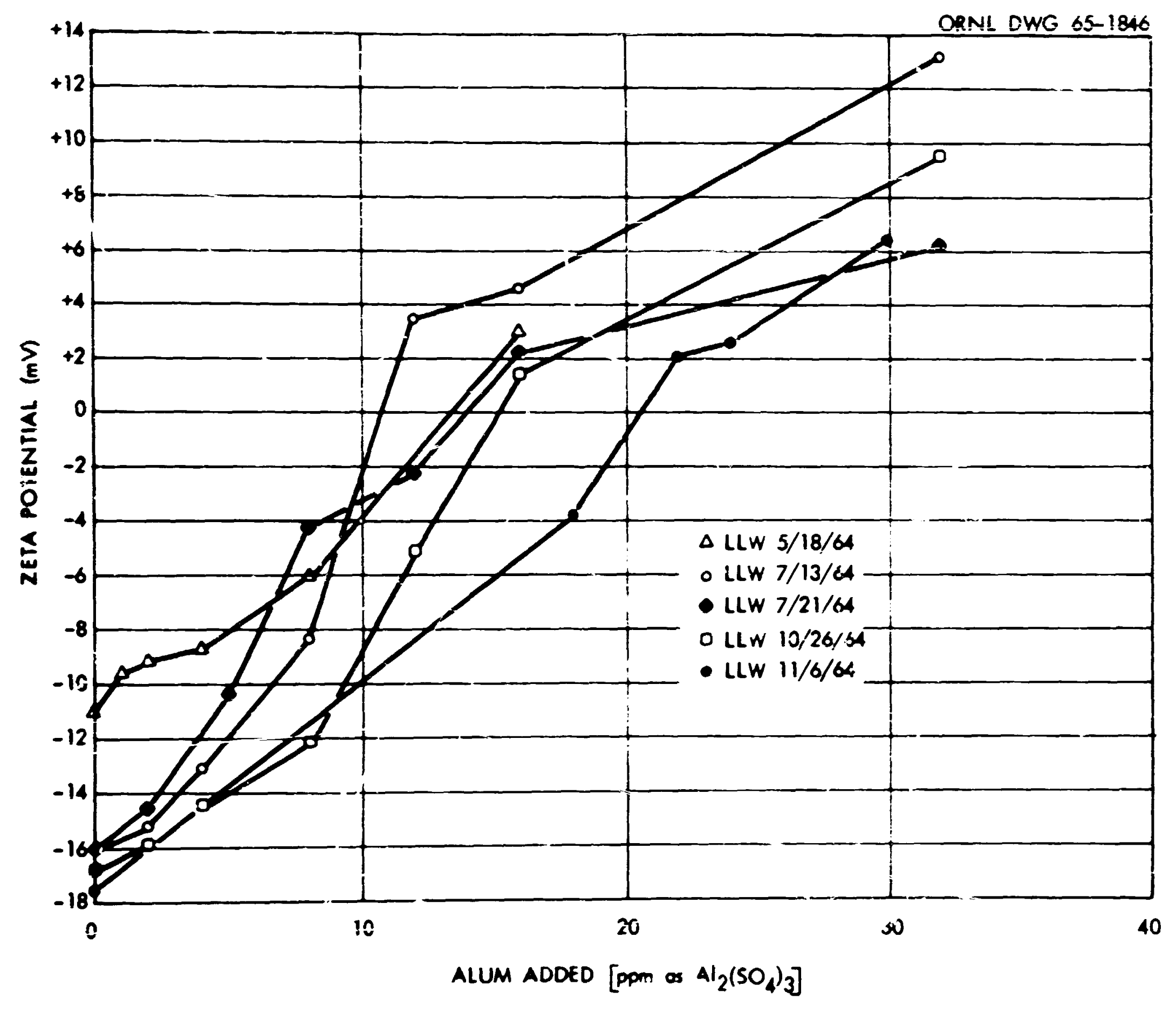

Fig. 8. Alun: Coogulation of LLW, Using Zeta-Potential Control. 
Table 2. Changes in Zeta Potential When Coagulant Aids Are Us ed in Conjunction with Alum Clarification

\begin{tabular}{|c|c|c|c|c|c|}
\hline \multirow{2}{*}{$\begin{array}{c}\text { Date } \\
\text { ORNL-LLW } \\
\text { Sainple } \\
\text { Was Taken }\end{array}$} & \multicolumn{3}{|c|}{ Coagulant Aid } & \multirow{2}{*}{$\begin{array}{l}\text { Alum } \\
\text { Conc: } \\
\text { (ppri) }\end{array}$} & \multirow{2}{*}{$\begin{array}{c}\text { Zeta } \\
\text { Potential } \\
\text { (mv) }\end{array}$} \\
\hline & Type & Purpose & $\begin{array}{l}\text { Conc. } \\
\text { (ppm) }\end{array}$ & & \\
\hline \multirow[t]{6}{*}{$7-13-64$} & Grisndite clay & To densify aluril flor. & 0 & 0 & -16.2 \\
\hline & & & 0 & 13 & 0 \\
\hline & & & 10 & 13 & 0 \\
\hline & & & 20 & 12 & 0 \\
\hline & & & 40 & 11 & 0 \\
\hline & & & 80 & 10 & 0 \\
\hline \multirow[t]{8}{*}{$11-6-64$} & Activated silica & To toughen fragile alum fioc & 0 & 0 & -14.8 \\
\hline & & & 0 & 24 & +5.2 \\
\hline & & & 0.5 & 24 & +2.2 \\
\hline & & & 1.0 & 24 & -2.3 \\
\hline & & & 2.0 & 24 & -5.8 \\
\hline & & & 5.0 & 24 & -10.2 \\
\hline & & & 10.0 & 24 & $-12 . j$ \\
\hline & & & 15.0 & 24 & -14.2 \\
\hline \multirow[t]{6}{*}{$7-13-i 4$} & Primafloc $C-3^{a}$ & To aid in agglomeration during & 0 & 7 & -5.7 \\
\hline & & flocculation & 0 & $7^{b}$ & -8.0 \\
\hline & & & 0.5 & $p^{b}$ & +3.1 \\
\hline & & & 1.0 & $7^{b}$ & +8.2 \\
\hline & & & 1.5 & $y^{b}$ & +11.2 \\
\hline & & & 2.0 & $7^{b}$ & +12.7 \\
\hline
\end{tabular}

${ }^{a}$ A cationic, medium-length-chain polyamine with a molecular weight of 10,000 to 20,000; froduct of Rohm and Haas Co., Philadelphia, Pa.

${ }^{b} 7$ ppm of aivin and 40 ppni of Grundite clay. 
2. Activated silica, which can be added to toughen the fragile alum floc, increases the amount of alum subsequently needed to attain zero ZP. (The ZP of activated silica in tap water is about $-15 \mathrm{mv}$, which is about the same as that of the suspensoids in ORNL-LLW.)

3. Additions of small amounts of organic poly iectrolytes such as Primafloc C-3, which can be added to the waste water cifte: the flash-mixing step to assist in floc agglomeration, produce grefater changes in ZP than imrganic coaguiants such os alum; for example, only 0.5 pom of Primafloc C-3 shifted the ZP of the suspended sarticles in LLW from about -6 to $+3 \mathrm{mv}$ (Table 2 ).

Microscopic examination of the aluminum hydroxide floc showed that flash mixing of $1750 \mathrm{rpm}$ caused the alum to be distributed more rapidly and more uniformly, and resulted in a more-complete enmeshing of the suspenscids, than mixing at 200 to $300 \mathrm{rom}$ (assuming that $300 \mathrm{rpm}$ is the maximum speed obtainable with a stsinard laboratory stirrer). This result agrees with the work of Riddick, ${ }^{18}$ who reported that, in the first one-thousandth of a second following the addition of alum, the hydious oxide polymer either encapsulates a colloid or unites with another alum polymer. The latrer action results in useless floc formation.

Optimum clarification conlitions were established by deiernining the cmount of solid that remairs suspended in the supernate in the jar tests. After a sestilirg time of $30 \mathrm{~min}, 250 \mathrm{ml}$ of the supernate in each jar was filiered through a $0.45-\mu$ Millipore filter, und the particulate concentration on the fiiter was determined. Best results were sbtained when $\mathrm{Al}_{2}\left(\mathrm{SO}_{4}\right)_{3}$ Jin $\mathrm{SiO}_{2}$ were sdided succest vely to give respective concentrations of $20=30$ and $0.5 \mathrm{ppm}$ (Fig. 9). In this cose, the overage $Z P$ of tile suspended sclids in the waste incressed from on origina! $=14$ to $-17 \mathrm{mv}$ to $+2.5 \mathrm{mv}$. After this trearment, only 20 porticles were found to be present per square centimeter of membrane filter area per rillhiier of clarified waste, as compared with 300 particles for the raw waste. 


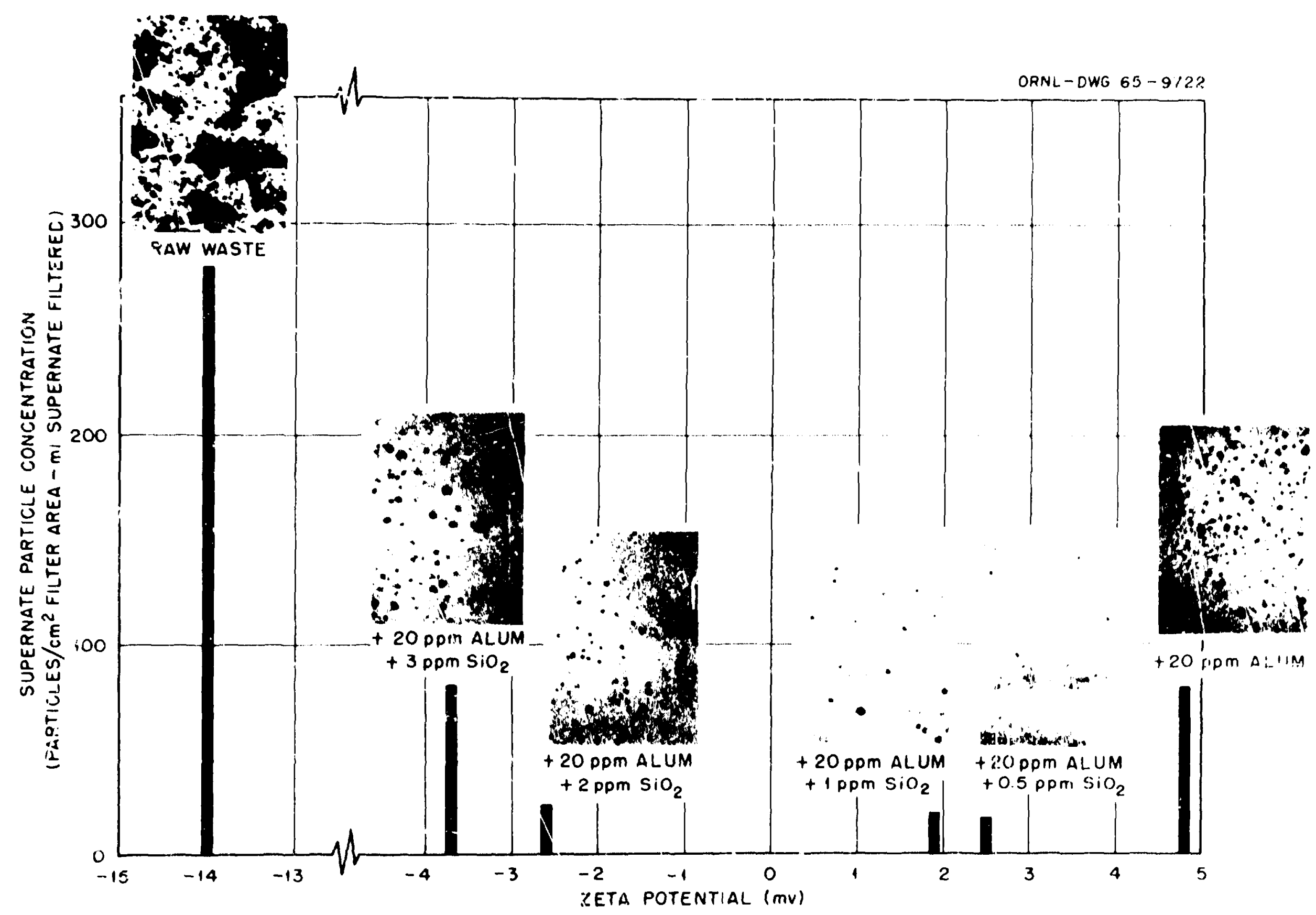

Fig. 9. Solids Filtered out of Treated Waste Supernatant onto a Membrane Filter at a Żeta Potential of $+2.5 \mathrm{mv}$. Jar-test conditions: $30 \mathrm{~min}$ of flocculation followed by $30 \mathrm{~min}$ of settling. 
The clarificotion of recycle waste water containing o low cencentration of totul dissolved solids (i.e., a specific conductance of $\sim 50$ micromhos/ $\mathrm{cm}$ ) had to be reated differently from LLW; this water required only about one-fifth to onetenih si the quantity of alum used in the treatment of OR̃NL-LLW havirg a concentration of tota! disoived solids similar to that of tap water (i.e., s specific cconductance cf $\sim 300$ micromhos/crm). Both activated silica and a nctionic polye'ectrolyte ware needed as coogulant aids in order to improve the setiling characteristics of the alum floc formed. Neither the addition of a polyelectralyte nor an alum-activated $s: i:=z$ trectment clone produced a clarified product of the quality obtained by using the activated silica and polyelectrolyte in cors:ination as coogulant aids.

Ja. tesis at $\mathrm{pH} 7$, which is the optimum pH for alum floc formation, demorstrated that, in the presence of a polyphosphate (a constituent of syndets), alum fiscculaticn and clarification are difficult. This is particularly true for water having a low calcium content (e.g., recycle water). The fomation of alum floc was studiea in distilled water containing 25 to 30 ppm of ortho-, pyro-, tripcty-. or hexametc= phosphate (as $\mathrm{PO}_{4}^{3-}$ ). Alum flor was formed ir orthophosphate solution Luin in the preserice and in the absence of scicium, and antiophosphate was removed irig. 10). In pilyphosphate sal.itiuns containing $60 \mathrm{pim}$ of $\mathrm{Al}_{2}\left(\mathrm{SO}_{4}\right)_{3}$, no floc was formed in tile absence of calcium. With ine addition of $30 \mathrm{ppm}$ of $\mathrm{Ca}^{2+}$, an alum floc was formed immediate $i y$, and 80 to $95 \%$ of each of the polyphosphates was removed. Results of deiailed coiumn sorption tests with activated alumina. which is dehydrated alum floc (with less surface area), indicate that polyphosphate sorption was significantly higher when the calcium/phosphate mole ratio was 1.0 or higher; jar tests were made under conditions where these ratios "aried from 0 to 3.0. Thus, when polyphosphates are present in recycle water, the calcium/phosphate mole ratio should probably be at least 1.0 in orcier to achieve optimum clarification with a minimum amount of alum. 


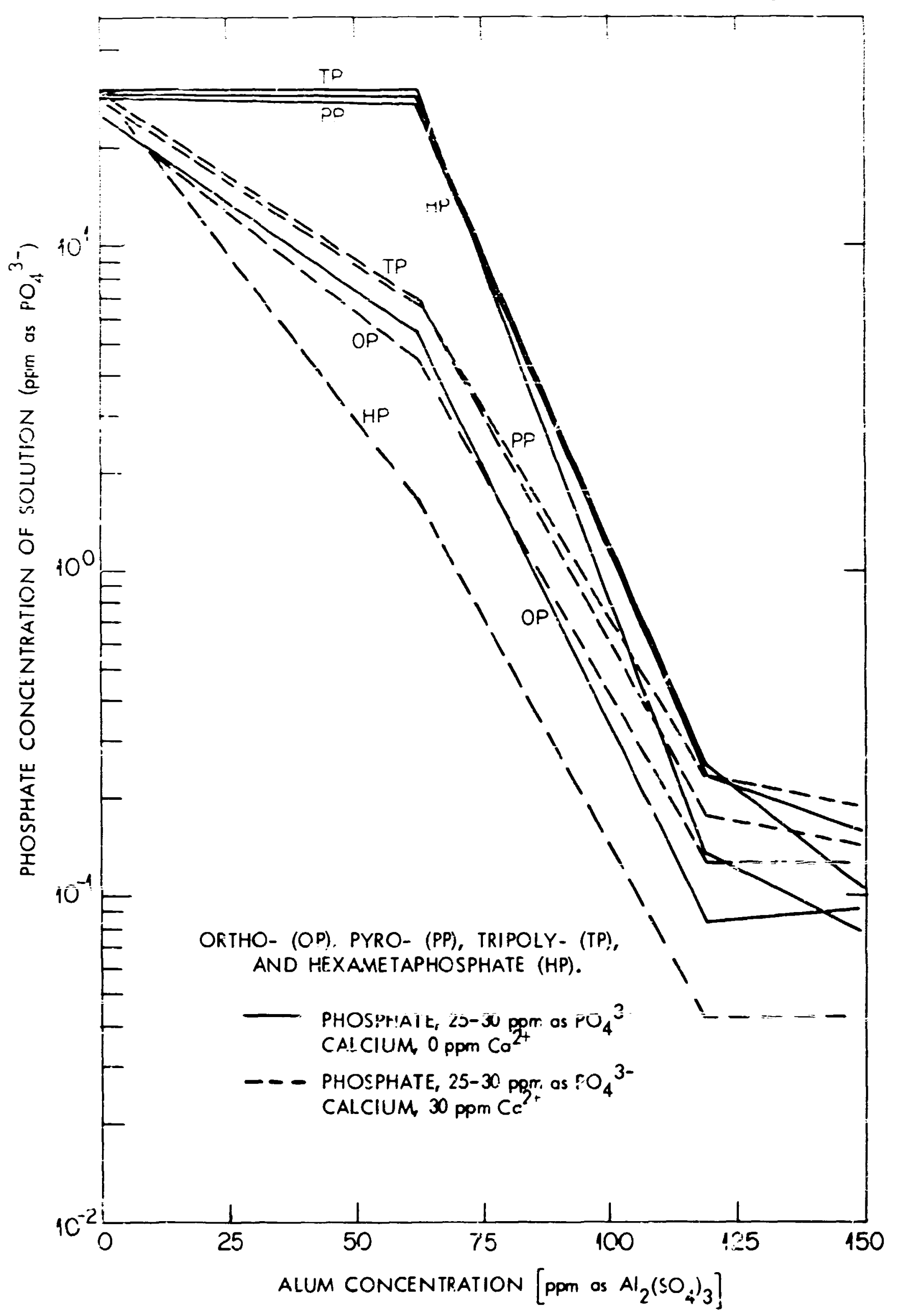

Fig. î. Aium Filocculation. Effect of calcium ion on phosphate removal at pH 7. 


\section{CONCLUSIONis}

Misro-pilot plant iests of a water rec;:cle prosess demonstrated the feasibility of using a closed-rycle me thod to trsat low-level radioactive waste having a low solt content. This process would allow the return of demineralized, well-decontaminated iecycle water to a nuclear installacion for reuse. It represents an improvement over the traditional "treat and discharge" methods of treatment. The fleccuistionclorification treot!nent reduced the solids content (turbidity) of ORNL-LLW from 10 to less than 0.C5 JTU, a level that is comparable to that of high-quality distilled water. Overall decontamination jactors of 1000 to 10,000 were dibtained for all mojor radiooctive species up to 2400 volumes of waste rreated per bed volume of cation resin. The product water met U. S. Public Heal th Service standards for the rodiooctive elements daterm! ned (i.e., less than $2 \%$ of the MPC for a 168-hr week if 131 is exclisoed; ( $10 \%$ of the MPC if ${ }^{131} 1$ is included). Specific conductance can be used as a simple indicator of resin-bed exhoustion since the breakthrough of bulk ions has been found to precede breakthrough of radioelements. Before breokthrough, ihe DF for demineralization was 200.

\section{ACKNOWIEDGAENVT}

The authors wish to express their thanks to R. E. Bianco, W. E. Clark, and J. T. Roberts for the ir technical assistance. Operation of the micro-pilot plant by G. D. Dovis is also grotefully acknowledged.

\section{REFERENCES}

1. Proceedings of Practices in the Treotment of Low- and Intermedioia-Le: 1 Rodiooctive W/astes, STI/PUB/116, IAEA, Vienin, 1966.

2. Technology of Rodiooctiva Waste Manogement Avoiding Enviromental Disposal, STI/DUC/10/27, IAF.A, Vienino, 1964. 
3. H. IV. Godbee, J. H. Goode, and R. E. Blonco, 'Development of a Process for Incorporation of Radiooctive Woste Solutions ard Slurties in Emulsified Asphalt," Environ. Sci. Technol. 2, 10,34-40 (1968).

4. C. L. Fitzgeraid, H. W. Godtee, R. E. B!sicco, and W. Davis, Jr., "The Feasibility of Incorporating Rodioortive Wostes in Asphalt or Polyethylene," Trans. Am. Nucl. Soc. 12(1), 29-30 (1969); also submitted for publication in Nuclear Applications and Technology.

5. T. M Riddick, "Zeto Poiential: New Tool for Watez Treatinent. Port 1," Chem. Eng. 68 13), 121 (196i); T. M. Riddick, "Zeto Potential: New Tool for Wust Treatment. Fort II," Chem. Eno. 68(14), 141 (1961).

3. J. T. Roberts and R. R. Holcomb, A Phenolic Resin lon Exchange Process for Decontaminating Low-Radioactivity-Level Process Water Waste, ORNL-3036 (Mor. 17, 1961).

7. R. R. Hol comi, Low -Rodioactive Level Waste Tizzinent. Part 1. Laboratory Development of a Scovenging-Precipitation lon-Exchange Process for Decontomination of Process Water Waste, ORNL-3322 (June 25, 1963).

8. R. E. Brooksbserk et al., Low-Rodiooctive Level Woste Treatment. Port 2. Filot Plant Demonstration of the Removal of Activity from Low-Level Process Wastes by a Senvenging-Precipitation lon-Exchange Process, ORNL-3349 (May 13, 1963).

9. L. J. Kiriz and M. Ichikowa, Pilot Plant Demonstration of the Decontamination of Low-Level Process Wastes by a Recycle Scavenging-Precipitation IonExchonge Process. ORNL-3863 (December 1965).

10. J. W. Gossetr, Chem. Process. (Chicogo) 28, 29 (1965).

11. I. D. Abdel-Razek, A Study of the Sorption of Cubalt by Activated Carbon, M. S. Thesis, University of Tannessee, Kroxville (August 1966;. 
12. C. P. Staut, Limitations on Water Treatment thethods for Removing Radioactive Contam: iants, Public Health Rept. (U. ؟.) 70, 897 (1965).

13. 11. S. Dept. of Commerce, "Maximum Permissible Body Burdens and Maximum Permissible Conzentrations of Radionuclides in Air and in Water for Occupo:ional Exn.sure;" NES Handbook 69, 1959.

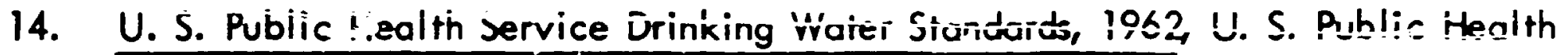

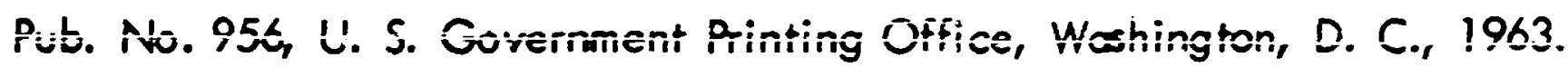

15. J. H. Neale, Advanced Waste Treatment by Distillation, U. S. Public Health Service Publication No. 999-Y.P-9 (AWTR-7) (March 1964), p. 5.

16. T. M. Riddick, Control of Colloid Stability Through Zeta Potential, Chaps. 4 and 5, published for Zeta-Meter, Inc., by !.ivingston Publishing Company, Wynnewood, Penn., 1968.

17. T. M. Riddick, "Zeta Potential and Iis Application to Difficult Waters," J. Am. Woter Works Assoc. 53, 1007 (1961).

18. T. M. Risidick, Toppi 47, 171 (1964). 

$-$

-

$-$ 